\title{
MENINGKATKAN HASIL BELAJAR SISWA MELALUI MODEL PEMBELAJARAN KOOPERATIF TIPE JIGSAW PADA PELAJARAN IPS MATERI POKOK INTERAKSI MANUSIA DENGAN LINGKUNGAN KELAS VII ${ }_{B}$ MTs NEGERI 1 KONAWE SELATAN
}

\author{
Sutriatno ${ }^{1}$ \\ ${ }^{1}$ Program Studi Pendidikan Geografi, Universitas Halu Oleo, Kendari.
}

\begin{abstract}
This is indicated by the average score of each cycle, were cyclence I the average score of the student activity is 2,6 , which is sufficient category, increases in cycle II to 3.5 which is in the good category. 2) teacher teaching activity by applying jigsaw type cooperative learning model in each cycle tends to increase. This is indicated by the average score on each cycle, where in cycle I the average score of teacher activity is 2.8 which categorized enough and increased in cycle II to 3.5 that categorized well. 3) learning result of IPS students of class VIIb MTsN Konawe South can be leveled by applying jigsaw type cooperative learning model on the subject matter of human interaction with its environment, where in cycle I that obtained the lowest value 50 , highest score 87 , average score 72.4 and mastery studies by $68 \%$ who have not reached KKM or from 31 students only 21 people who scored $\geq 70$. In cycle II obtained the lowest score of 56 highest score 94, average score 76 and mastery learnig completeness in cycle II has increased from 31 students there are 26 students got the score of $\geq 70$ with the percentage of learning result completeness is $84 \%$.
\end{abstract}

\section{Key word: model of learning, process, learning outcomes}

\section{PENDAHULUAN}

Pendidikan merupakan sebuah proses untuk mengubah jati diri seorang siswa untuk lebih maju. Pendidikan merupakan salah satu proses pembaharuan makna pengalaman dan proses yang terjadi secara terus menerus (abadi) dari penyesuaian yang lebih tinggi bagi mahluk manusia yang telah berkembang secara fisik dan mental, bebas dan sadar kepada Tuhan, seperti yang termanifestasi dalam alam sekitar, intelektual, emosional, dan kemanusian dari manusia (Listyarti, 2012:2). Kaitannya dengan pendidikan, Ilmu Pengetahuan Sosial memiliki peran yang cukup besar dalam pencapaian tujuan pembangunan nasional.

Peran dan kedudukan pembelajaran IPS sungguh sangat strategis. Tidak saja bagi siswa tetapi juga bagi kelangsungan hidup berbangsa dan bernegara Indonesia. Mata pelajaran IPS menjadi strategis karena mengkaji seluruh aspek kehidupan sosial kita. Di dalamnya kita bisa mempelajari kehidupan bangsa dari dimensi sejarah, geografi, ekonomi, politik, antropologi, sosiologi, filsafat, dan psikologi sosialnya. Diharapkan siswa mampu memetik pelajaran untuk kehidupan sosial kemasyarakatan yang lebih baik. Selain itu, siswa nantinya bisa memiliki kecerdasan sosial yang tinggi, pemikiran yang rasional, tidak emosional dalam menyikapi permasalahan sosial yang ada di lingkungannya, serta aktif dalam mengembangkan kehidupan berbangsa dan bernegara. sehingga penting agar dapat dikuasai sedini mungkin oleh para siswa. Penguasaan pelajaran IPS oleh siswa tentu seharusnya melalui proses pembelajaran yang terencana dengan baik. Namun dalam upaya pelaksanaan proses pembelajaran IPS yang baik untuk meningkatkan hasil belajar IPS siswa masih menjadi tantangan yang dihadapi oleh guru di sekolah. 
Berdasarkan hasil wawancara peneliti dengan guru mata pelajaran IPS di MTs Negeri 1 Konawe Selatan, menunjukan bahwa penguasaan siswa pada materi pembelajaran IPS masih rendah, salah satunya pada materi Interaksi social Dengan Lingkungan.

Rendahnya hasil belajar siswa tersebut ditunjukan dengan rata-rata nilai IPS siswa kelas $\mathrm{VII}_{\mathrm{B}}$ pada ulangan harian siswa materiInteraksi manusi dengan lingkungan tersebut hanya mencapai 55. Nilai rata-rata ulangan harian tersebut berada di bawah standar ketuntasan belajar berdasarkan ketentuan sekolah, yakni sebesar 70 . Rendahnya hasil belajar IPS siswa tersebut dipengaruhi beberapa faktor diantaranya adalah kemampuan siswa yang bervariasi, kesulitan siswa dalam memahami konsep materi yang sedang diajarkan dan kesulitan bagi guru untuk menciptakan suasana belajar yang menarik. Selain itu, ditemukan pula siswa yang bersifat individualistik yaitu siswa yang memiliki kemampuan lebih tetapi tidak mau berbagi dengan siswa lainnya yang memiliki kemampuan rendah.

Setelah peneliti melakukan observasidikelas VII $_{\mathrm{B}} \mathrm{MTs}$ Negeri 1 Konawe selatandalam proses pembelajaran IPS guru masih dominan menggunakan model pembelajaran konvensional, dimana guru lebih aktif dari pada siswa. Penyajian materi lebih fokus dari guru ke siswa dan siswa lebih banyak mendengar dan memperhatikan penjelasan guru. Guru memberikan soal dan menyelesaikannya secara langsung tanpa memberi kesempatan kepada siswa untuk mempresentasikan idenya. Kurangnya latihan yang diberikan guru kepada siswa dalam menyelesaikan masalah mengakibatkan siswa lebih banyak mendengar dan memperhatikan penjelasan guru.

Penggunaan model pembelajaran konvensional dalam proses belajar mengajar sangat memungkinkan siswa merasa bosandan kurang aktif dalam belajar karena cara mengajar guru yang bersifat monoton. Hal inidiperkuat dengan ditemukan banyaknya siswa yang melamun, bercerita dengan temansebangku dan rebutan pulpen pada saat proses pembelajaran berlangsung. Siswa tidak diberi kesempatan seluasluasnya untuk mengembangkan daya pikir dan kreatifitasnya sehingga dapat dipastikan bahwa siswa yang pintar akan semakin pintar dan siswa yang kurang akan semakin kurang.

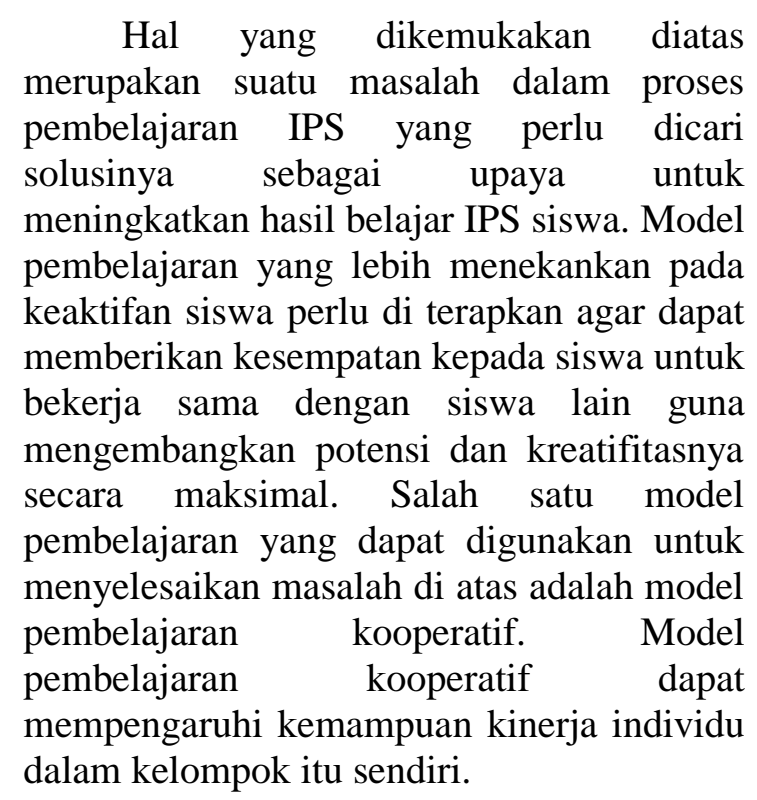

Oleh karena itu, tiap siswa dapat mengukur kemampuan mereka dan mengetahui kekurangannya masing-masing sebelum masuk dalam kelompoknya agar tidak terjadi diskomunikasi antar anggota kelompok akibat siswa tidak mengetahui hal-hal apa saja yang perlu ia diskusikan dalam kelompoknya. Jadi, sebelum masuk dalam kelompok, siswa terlebih dahulu harus belajar secara individu untuk mengetahui kelemahan dan kekurangannya

Diantara tipe-tipe dalam model pembelajaran kooperatif, terdapat Model pembelajaran kooperatif tipe Jigsaw dapat dipilih sebagai alternatif model pada pembelajaran IPS di MTs Negeri 1 Konawe Selatan. Jika dilihat dari kelebihan model pembelajaran tipe Jigsawini terdapat beberapa alasan yang mendukung yaitu, dapat meningkatkan kerjasama maupun partisipasi siswa karena setiap anggota memiliki tanggung jawab dan tugas terhadap kelompoknya. Lebih khusus lagi dalam 
model pembelajaran Jigsaw terdapat dua macam kegiatan yaitu kelompok asal dan kelompok ahli. Siswa tidak hanya menunggu bantuan dari guru, melainkan siswa dapat meminta bantuan maupun berdiskusi kepada temannya yang lain. Siswa yang memiliki kemampuan lebih akan mendapatkan kesempatan untuk meningkatkan kemampuan akademiknya dengan menjadi tutor sebaya bagi siswa yang memiliki kemampuan kurang dalam pembelajaran, sedangkan siswa yang lemah akan menjadi terbantu sehingga terjadi interaksi yang aktif dan mendorong partisipasi setiap anggota kelompok dalam belajar.

Berdasarkan pemikiran yang telah dikemukakan diatas, peneliti tertarik untuk melakukan suatu penelitian dengan judul “ Meningkatkan Hasil Belajar Siswa Melalui Model Pembelajaran Kooperatif Tipe Jigsaw pada Pelajaran IPS Materi Pokok Interaksi Manusia dengan Lingkungan Alam, Sosial, Budaya dan Ekonomi Kelas VIIB $_{B}$ MTs Negeri 1 Konawe.

Apakah aktifitas belajar siswa kelas $\mathrm{VII}_{\mathrm{B}}$ MTs Negeri 1 Konawe Selatan pada Materi Pokok Interaksi Manusia dengan Lingkungan Alam, Sosial, Budaya dan Ekonomi dapat ditingkatkan Melalui model pembelajaran kooperatif dengan tipe Jigsaw ? 1)Apakah aktifitas mengajar guru kelas VII $_{B}$ MTs Negeri 1 Konawe Selatan pada Materi Pokok Interaksi Manusia dengan Lingkungan Alam, Sosial, Budaya dan Ekonomi dapat ditingkatkan Melalui model pembelajaran kooperatif dengan tipe Jigsaw?. 2)Apakah hasil belajar siswa kelas $\mathrm{VII}_{B}$ MTs Negeri 1 Konawe Selatan pada Materi Pokok Interaksi Manusia dengan Lingkungan Alam, Sosial, Budaya dan Ekonomi dapat ditingkatkan Melalui model pembelajaran kooperatif dengan tipe Jigsaw ?, Meningkatkan aktifitas belajar siswa kelas $\mathrm{VII}_{B}$ MTs Negeri 1 Konawe Selatan pada Materi Pokok Interaksi Manusia dengan Lingkungan Alam, Sosial, Budaya dan Ekonomi Melalui Model Pembelajaran Kooperatif tipe Jigsaw. Meningkatkan aktifitas mengajar guru kelas VII $\mathrm{B}_{\mathrm{B}}$ MTs Negeri 1 Konawe Selatan pada Materi Pokok Interaksi Manusia dengan
Lingkungan Alam, Sosial, Budaya dan Ekonomi Melalui Model Pembelajaran Kooperatif tipe Jigsaw. Meningkatkan hasil belajar siswa kelas $\mathrm{VII}_{\mathrm{B}}$ MTs Negeri 1 Konawe Selatan pada Materi Pokok Interaksi Manusia dengan Lingkungan Alam, Sosial, Budaya dan Ekonomi Melalui Model Pembelajaran Kooperatif tipe Jigsaw.

Dalam penelitian di harapkan dapat memberikan manfaat;1) Untuk guru, sebagai informasi tentang model pembelajaran dan sebagai metode untuk memperbaiki dan meningkatkan kulaitas belajar mengajar.2) Untuk siswa, dapat berpartisipasi aktif selama proses pembelajaran dan dapat meningkatkan pemahaman siswa dalam belajar khusunya IPS pada Materi Pokok Interaksi Manusia dengan Lingkungan Alam, Sosial, Budaya dan Ekonomi.3) Untuk sekolah, dapat memberikan sumbangan yang baik bagi sekolah dalam memperbaiki kualitas proses pembelajaran IPS.

Belajar merupakan suatu proses dasar dari perkembangan hidup manusia. Dengan belajar manusia dapat melakukan perubahan tingkah laku, dan kualitas individu sehingga dapat berkembang. Belajar merupakan kegiatan berproses dan merupakan unsur yang sangat penting dalam setiap jenjang pendidikan. Dalam keseluruhan proses pendidikan, kegiatan belajar merupakan kegiatan yang paling pokok dan penting dalam mencapai tujuan pendidikan. Ini berarti berhasil tidaknya pencapaian tujuan pendidikan banyak tergantung pada proses belajar yang dialami siswa sebagai peserta didik.

Belajar adalah suatu proses usaha yang dilakukan untuk memperoleh suatu perubahan tingkah laku yang baru secara keseluruhan sebagai hasil pengamalan itu sendiri dan interaksi dengan lingkunganya, Purwanto (1992:83). mendefinisikan belajar adalah suatu perubahan dalam tingkah laku, di mana perubahan itu dapat mengarah pada tingkah laku yang lebih baik atau sebaliknya dan terjadi Melalui latihan atau pengalaman (Slameto, 1992:2). 
Belajar sebagai suatu proses yang mengakibatkan adanya perubahan perilaku ( change in behavior or performance), di mana perubahan itu dapat aktual yaitu yang tampak tetapi juga dapat bersifat potensial, yang tidak tampak pada saat itu akan tampak pada lain kesempatan. Perubahan yang disebabkan bersifat relatif permanen, yaitu perubahan itu akan bertahan dalam waktu lama (Walgito, 1989:167).

Belajar adalah suatu proses yang ditandai dengan adanya perubahan pada diri seseorang. Perubahan sebagai hasil belajar dapat ditunjukan dalam berbagai bentuk, misalnya peribahan tingkah laku, pemahaman, pengetahuan yang dihasilkan oleh adanya interaksi orang itu dengan lingkungan sehingga diperoleh jumlah kecakapan dan pengetahuan (Hudoyo, 1988:1).

Belajar adalah kegiatan psiko phisics menuju keperkembangan pribadi. Kemudian dalam arti sempit belajar diartikan sebagai usaha penguasaan materi ilmu pengetahuan yang maupun sebagian kegiatan menuju terbentuknya kepribadian seutuhnya (Sardiman, 2007:20). Definisi belajar adalah suatu aktifitas mental/psikis yang berlangsung antara interaksi aktif dengan lingkungan yang menghasilkan sejumlah perubahan dalam pengetahuanpengetahuan, keterampilan dan sikap, perubahan itu bersifat secara relativ konstan dan bebas, Gagne dalam Ratna Wilis (2011:11). Belajar adalah suatu proses di mana organisme berubah perilakunya sebagai akibat dari pengalaman (Winkel, 2007:59).

Dari beberapa pendapat para ahli di atas, maka disimpulkan bahwa belajar merupakan suatu perubahan dalam tingkah laku di mana perubahan itu dapat mengarah kepada tingkah laku yang lebih baik, tetapi juga ada kemungkinan mengarah kepada tingkah laku yang lebih buruk, dan merupakan suatu perubahan yang terjadi Melalui latihan dan pengalaman.

\section{Deskripsi mengajar}

Masalah mengajar telah menjadi persoalan bagi para ahli pendidikan sejak dulu sampai sekarang. Pengertian mengajar telah mengalami perkembangan, bahkan hingga dewasa ini belum ada definisi yang tepat mengenai mengajar itu.Alvin Howard dalam Roestyiah mendefinisakn mengajar sebagai suatu aktifitas untuk mencoba menolong, membimbing seseorang untuk mendapatkan, mengubah atau mengembangkan keterampilanya (skill), bakat (atitude), cita-cita (ideals), penghargaan (appreciations) dan pengetahuan (knowledge). Mengajar adalah proses mengatur, mengorganisasi lingkungan yang ada disekitar siswa sehingga dapat menumbuhkan dan mendorong siswa melakukan proses belajar (Sudjana, 2007:29).

Mengajar adalah penyerahan kebudayaan berupa pengalaman dan kecakapan kepada anak didik kita. Adapun definisi-definisi lain di negara-negara modern yang sudah maju mengatakan bahwa mengajar adalah bimbingan kepada siswa dalam proses belajar. Definisi ini menunjukan bahwa yang aktif adalah siswa, yang mengalami proses belajar. Sedangkan guru hanya membimbing, menunjukan jalan dengan memperhitungkan kepribadian siswa, kesempatan untuk berbuat dan aktif berpikir lebih banyak diberikan kepada siswa (Slameto, 1995:29).

Mengajar adalah suatu aktifitas mengorganisasi atau mengatur lingkungan sebaik-baiknya dan menghubungkanya dengan anak, sehingga terjadi proses belajar (Syah, 2003:182). Mengajar merupakan usaha untuk menciptakan kondisi lingkungan atau sistem lingkungan yang mendukung dan memungkinkan untuk berlangsungnya proses belajar. Mengajar adalah menyampaikan ilmu pengetahuan pada anak didik dengan suatu harapan terjadi proses pemahaman (Sardiman, 2007:47). Mengajar adalah mengaorganisasi hal-hal yang berhubungan dengan belajar yang dapat dilihat dari segala macam situasi belajar yang baik maupun yang buruk untuk memperoleh hasil-hasil yang autentik, 
sungguh-sungguh dan yang sejati (Nasution, 1995:8).

Berdasarkan beberapa pendapat para ahli di atas maka dapat disimpulkan bahwa mengajar adalah upaya yang dilakukan dalam bentuk pemberian bimbingan dan pengarahan, termaksud mengatur dan mengorganisasikan lingkungan disekitar siswa sehingga memungkinkan untuk melakukan proses belajar.

\section{B. Pengertian Hasil Belajar}

Dalam kegiatan belajar mengajar, hasil belajar yang diharapkan dapat dicapai oleh siswa, penting diketahui oleh guru dalam merencanakan kegiatan belajar mengajar secara tepat. Secara umum, dapat didefinisikan bahwa hasil belajar adalah penguasaan yang diperoleh siswa setelah mengikuti kegiatan belajar mengajar.

Hasil belajar adalah mencerminkan tujuan pada tingkat tertentu yang berhasil dicapai oleh peserta didik (siswa) yang dinyatakan dengan angka atau huruf. Dalam bidang studi IPS hasil belajar yang dimaksudkan adalah nilai kemampuan siswa setelah dilakukan evaluasi pada pembelajaran IPS (Sudjana, 2015:13).

Hasil belajar merupakan hasil dari suatu interaksi tindak belajar dan tindak mengajar. Dari sisi guru, tindak mengajar diakhiri dengan proses evaluasi hasil belajar. Dari sisi siswa, hasil belajar merupakan berakhirnya penggal dan puncak proses belajar. Hasil belajar, untuk sebagian orang adalah berkat tindak guru, suatu pencapaian tujuan pengajaran. Pada bagian lain, merupakan peningkatan kemampuan mental siswa (Dimyati, 2009:3).

Penampilan-penampilan yang dapat diamati sebagai hasil-hasil belajar tersebut kemampuan-kemampuan (capabilities). Ada lima hasil belajar yang dikemukakan Gagne yaitu; a)Keterampilan intelektual, atau pengetahuan prosedural yang mencakup belajar konsep, prinsip dan pemecahan masalah yang diperoleh Melalui penyajian materi disekolah. b)Strategi kognitif, yaitu kemampuan untuk memecahkan masalah- masalah baru dengan jalan mengatur proses internal masing-masing individu dalam memperhatikan, belajar, mengingat, dan berpikir.c)Informasi verbal, yaitu kemampuan untuk mendeskripsikan sesuatu dengan kata-kata dengan jalan mengatur informasi-informasi yang relevan. d) Keterampilan motorik, yaitu kemampuan untuk melaksanakan dan mengkoordinasikan gerakan-gerakan yang berhubungan dengan otot. e) Sikap, yaitu suatu kemampuan internal internal yang mempengaruhi tingkah laku seseorang yang didasari oleh emosi, kepercayaan-kepercayaan serta faktor intelektual (Gagne dalam Ratna Wilis, 2011:134-135).

Berdasarkan uraian di atas dapat disimpulkan bahwa hasil belajar adalah ukuran keberhasilan seorang siswa setelah mengikuti proses belajar yang berupa pengetahuan, pemahaman, sikap dan keterampilan tertentu disuatu tempat tertentu yang diketahui dengan memberikan hasil belajar sebagai alat ukur. Pengukuran hasil belajar berfungsi untuk mengetahui tercapai tidaknya indikator pembelajaran dan mengetahui tingkat penguasaan bahan pelajaran yang harus dikuasai siswa serta untuk mengetahui efektifitas model pengajaran yang digunakan dalam proses belajar mengajar.

\section{Model Pembelajaran Kooperatif Tipe Jigsaw}

\section{Pembelajaran Kooperatif}

Ide pembelajaran kooperatif kembali dikembangkan oleh para pakar psikologi pendidikan pada awal abad ke-20, didasari oleh adanya pendapat bahwa untuk belajar seseorang harus memiliki pasangan atau teman. Model pembelajaran kooperatif memanfaatkan adanya kecenderungan siswa untuk berinteraksi dan menjauhkan kesalahan tradisional, yaitu secara ketat mengelola tingkah laku siswa dalam kerja kelompok. Dengan demikian, siswa lebih memiliki kemungkinan tingkat berpikir yang lebih tinggi selama dan setelah diskusi dalam kelompok sehingga materi yang 
dipelajari melekat untuk periode waktu yang lama.

Pembelajaran kooperatif merupakan suatu model pembelajaran dengan menggunakan kelompok kecil, bekerja sama. Keberhasilan dari model ini sangat tergantung pada kemampuan aktifitas anggota kelompok. Pembelajaran ini sangat menyentuh hakikat manusia sebagai mahluk sosial yang berinteraksi, saling membantu kearah yang baik secara bersama (Buchari Alma, 2009:80).

Pembelajaran kooperatif adalah suatu model pembelajaran di mana siswa belajar dan bekerja dalam kelompok kecil secara kolaboratif yang anggotanya 4-6 orang, dengan struktur kelompok heterogen.

Tiga konsep sentral yang menjadi karakteristik pembelajaran kooperatif sebagaimana dikemukakan Slavin yaitu penghargaan kelompok, pertanggung jawaban individu dan kesempatan yang sama untuk berhasil (Buchari Alma, 2009:81).

Pembelajaran kooperatif atau pembelajaran gotong royong adalah sistem pengajaran yang memberikan kesempatan kepada anak didik untuk bekerja sama dengan sesama siswa dalam tugas-tugas yang berstruktur (Saputra, 2005:50). Sedangkan Johnson dan Johnson mengemukakan bahwa sistem pengajaran gotong royong atau pembelajaran kooperatif dapat didefinisikan sebagai sistem kerja atau belajar kelompok yang terstruktur, termaksud di dalam struktur ini adalah lima unsur pokok yaitu saling ketergantungan positif, tanggung jawab individual, interaksi personal, keahlian bekerja sama, dan proses kelompok (Lie, 2002:17).

Model pembelajaran kooperatif dikembangkan untuk setidaknya tiga tujuan pembelajaran penting, yaitu : (1) hasil belajar akademik, (2) penerimaan terhadap perbedaan individu menurut ras, budaya, kelas sosial, kemampuan dan ketidakmampuan, (3) pengembangan keterampilan sosial yang meliputi keterampilan kerja sama dan kolaborasi (Ibrahim, 2000:7).
Selain itu, enam tahapan di dalam pelajaran yang menggunakan pembelajaran kooperatif. Tahapan-tahapan tersebut adalah : (1) guru menyampaikan tujuan dan memotifasi siswa, (2) menyajikan informasi, (3) mengorganisasikan siswa ke dalam kelompok-kelompok belajar, membimbing kelompok bekerja dan belajar, (5) evaluasi, (6) memberikan penghargaan (Ibrahim, 2000:11).

Pembelajaran kooperatif berbeda dengan pembelajaran yang lain. Perbedaan tersebut dapat dilihat dari proses pembelajaran yang lebih menekankan proses kerja sama dalam kelompok. Tujuan yang ingin dicapai bukan hanya kemampuan akademik dalam pengertian penguasaan bahan pelajaran, tetapi juga adanya unsur kerja sama untuk penguasaan materi tersebut. Adanya kerja sama inilah yang menjadi ciri khas dari pembelajaran kooperatif (Sanjaya, 2006:143).

\section{METODE PENELITIAN}

Penelitian ini merupakan penelitian tindakan kelas (PTK). Penelitian ini akan dilaksanakan pada bulan Mei pada semester genap 2016/2017 bertempat di MTs Negeri 1 Konawe Selatan, kecamatan Konda. Peneliti memilih kelas VII $\mathrm{VI}_{\mathrm{B}} \mathrm{MTs}$ Negeri 1 Konawe Selatan sebagai tempat melakukan Penelitian Tindakan Kelas, karena peneliti mengajar di kelas tersebut sehingga peneliti mengetahui permasalahan siswa dalam proses pembelajaran IPS.

Selain itu model pembelajaran kooperatif tipe Jigsaw belum pernah diterapkan dikelas VII MTs Negeri 1 Konawe Selatan sehingga dalam penelitian tindakan kelas ini, peneliti menerapkan model pembelajaran kooperatif tipe Jigsaw

Subyek penelitian ini adalah guru dan siswa kelas VII MTs Negeri 1 Konawe Selatan. Jumlah siswa sebanyak 31 orang, terdiri dari 12 perempuan dan 19 laki-laki 
Penelitian ini akan dilaksanakan dalam beberapa siklus. Secara rinci rencana tindakan dalam penelitian ini adalah :

1. Perencanaan, kegiatan yang dilakukan dalam tahap ini adalah :

a. Membuat skenario pembelajaran dengan menggunakan pendekatan Jigsaw.

b. Membuat lembar observasi untuk melihat bagaimana kondisi belajar mengajar ketika pendekatan Jigsaw dilaksanakan.

c. Mempersiapkan angket refleksi siswa dalam pembelajaran. Angket ini diberikan diakhir pertemuan setiap siklus.

d. Membuat lembar kerja siswa.

e. Mendesain alat evaluasi untuk melihat apakah ada peningkatan hasil belajar siswa.

2. Pelaksanaan tindakan, kegiatan yang dilakukan dalam tahap ini adalah melaksanakan skenario pembelajaran yang telah dibuat.

3. Observasi/evaluasi, kegiatan yang dilakukan dalam tahap ini adalah observasi terhadap pelaksanaan tindakan dengan menggunakan lembar observasi yang telah dibuat serta melakukan evaluasi.

4. Refleksi, hasil yang diperoleh dalam tahap observasi dan evaluasi dikumpulkan dan dianalisis. Dari hasil refleksi ini didapat diketahui apakah proses yang diperoleh dari pelaksanaan tindakan yang telah mencapai ketuntasan hasil belajar siswa sesuai yang diharapkan. Jika belum tercapai, maka dilanjutkan ke siklus selanjutnya dengan melakukan revisi Melalui perbaikan rencana pembelajaran dan penekanan pada hal-hal yang belum dilakukan pada proses pembelajaran sebelumnya.

\section{HASIL PENELITIAN \\ Data Aktivitas Belajar Siswa}

Data mengenai aktifitas siswa kelas $\mathrm{VII}_{\mathrm{B}}$ MTs Negeri 1 Konawe Selatan selama pembelajaran dengan menggunakan model pembelajaran kooperatif tipe jigsaw di peroleh dengan menggunakan lembar observasi dengan cara memberikan skor pada setiap aspek aktifitas yang di lakukan oleh siswa sesuai dengan criteria yang telah di tentukan. Data mengenai penskoran aktifitas siswa pada setiap siklus dapat di lihat pada table 3.1 berikut

Tabel 3.1 Rata-rata aktifitas siswa pada setiap Siklus I dan II

\begin{tabular}{lllc}
\hline No & Aktivitas yang Dinilai & SIKLUS I & $\begin{array}{c}\text { SIKLUS } \\
\text { II }\end{array}$ \\
\hline 1 & mendengarkan dan memperhatikan penjelasan guru & 2.2 & 3.3 \\
\hline 2 & mengajukan pertanyaan pada guru & 2.6 & 3.3 \\
\hline 3 & kesediaan untuk memberikan ide dalam satu kelompok & 2.6 & 3.2 \\
\hline 4 & berdiskusi dengan kelompok dan memecahkan masalah & 2.6 & 3.3 \\
\hline 5 & membaca dan menelaah LKS yang diberikan & 2.6 & 3.1 \\
\hline 6 & melakukan kegiatan secara berkelompok & 2.6 & 3.3 \\
\hline 7 & kepedulian terhadap masalah yang dihadapi & 2.7 & 3.1 \\
\hline 8 & bekerja dengan kelompok baik dalam kelompok asal & 2.7 & 3.3 \\
\hline & maupun kelompok ahli & & 3.6 \\
\hline 9 & keaktifan siswa dalam kelompok dan memberikan masukan & 2.7 & \\
\hline
\end{tabular}




\begin{tabular}{llllc}
\hline \multicolumn{3}{l}{ kesepakatan diterima bersama } & & \\
\hline 10 & kemampuan menjaga kekompakan kelompok & 2.8 & 3.2 \\
\hline 11 & $\begin{array}{l}\text { menyimak peguatan dan koreksi yang diberikan guru } \\
\text { sebagai perbaikan }\end{array}$ & 2.7 & 3.6 \\
\hline 12 & $\begin{array}{l}\text { mempersentasekan hasil diskusi dan kerja kelompok di } \\
\text { depan kelas }\end{array}$ & 2.8 & \\
\hline 13 & $\begin{array}{l}\text { melakukan tanya jawab antara guru dan siswa setelah } \\
\text { mempersentasekan hasil diskusi }\end{array}$ & 2.7 & 3.6 \\
\hline KATEGORI & CUKUP & BAIK \\
\hline Sumber: Data diolah (2017) & & \\
\hline
\end{tabular}

Dari tabel 3.1 diatas ditunjukkan bahwa ratarata aktivitas belajar siswa terendah pada siklus I yaitu berada pada aktivitas siswa ke 1, 2, 3, 4, dan 5 yaitu pada Memotivasi Mendengarkan dan memperhatikan penjelasan guru, Mengajukan pertanyaan pada guru, Kesediaan untuk memberikan ide dalam satu kelompok, Berdiskusi dengan kelompok dan memecahkan masalah, Membaca dan menelaah LKS yang di berikan dan pada siklus II aktivitas belajar siswa menunjukkan peningkatan sebagaimana aktivitas terendah pada siklus I. Sedangkan aktivitas belajar siswa tertinggi pada siklus I berada pada aktivitas siswa nomor $1,2,4,6,8,9,11$, dan 13 dengan skor 3,3 dan 3,6 yaitumemotivasi mendengarkan dan memperhatikan penjelasan guru, mengajukan pertanyaan pada guru, kesediaan untuk memberikan ide dalamsatu kelompok, berdiskusi dengan kelompok dan memecahkan masalah, melakukan kegiatan secara berkelompok, bekerja dengan kelompok baik dalam kelompok asal maupun kelompok ahlli, keaktifan siswa dalam kelompok dan memberika masukan sebelum kesepakatan di terima bersama, menyimak penguatan dan koreksi yang di berika guru sebagai perbaikan, mempresentasekan hasil diskusi dan kerja kelompok di depan kelas, melakukan tanya jawab antara guru dan siswa setelah mempresentasekan hasil diskusi.

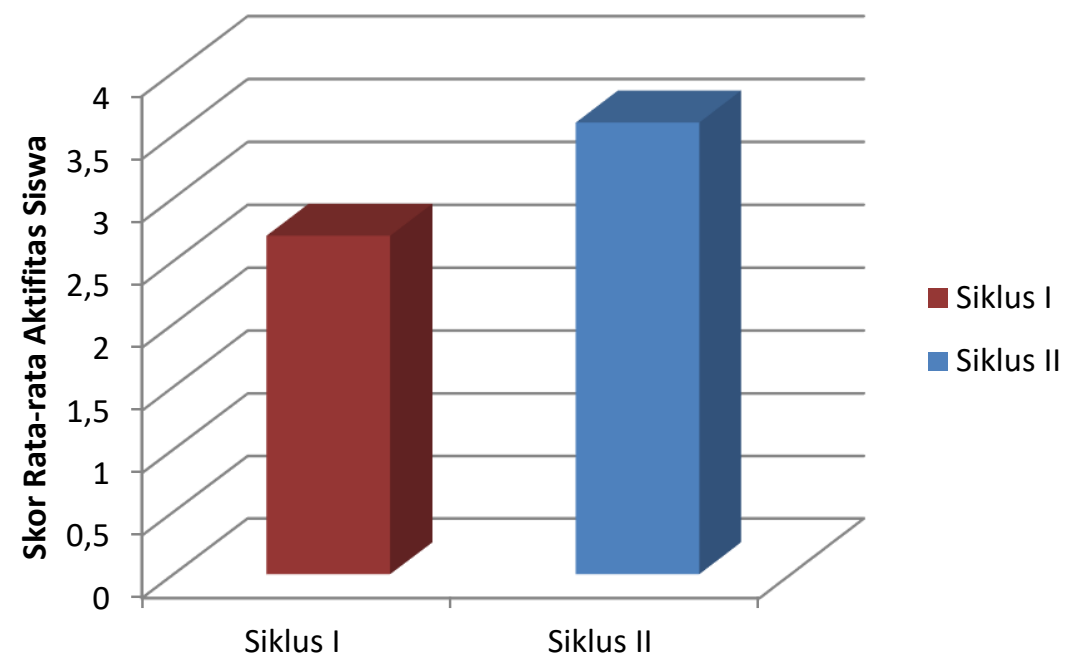

Diagram 3.1. Skor Rata-rata Aktivitas Belajar Siswa

Berdasarkan Gambar 3.1 di atas, diperoleh gambaran bahwa aktivitas siswa dalam 
kegiatan belajar mengajar dengan menerapkan pendekatan pembelajaran Kooperatif tipe jigsaw cenderung mengalami peningkatan. Hal ini ditunjukkan oleh skor rata-rata aktivitas siswa pada siklus I sebesar 2,7 dan pada siklus II aktivitas siswa mengalami peningkatan menjadi 3,6.

\begin{abstract}
Pengamatan aktifitas mengajar guru dengan pendekatan pembelajaran Kooperatif tipe jigsaw pada mata pelajaran IPS Geografi dipengamatan dengan memberikan skor 1 sampai 4 terhadap 17 indikator keterlaksanaan aktifitas mengajar guru.
\end{abstract}

\section{Data Aktivitas Mengajar Guru}

Tabel 3.2. Skor Rata-Rata Aktivitas Mengajar Guru Setiap Siklus

\begin{tabular}{|c|c|c|}
\hline Aspek yang di Amati & Siklus I & Siklus II \\
\hline \multicolumn{3}{|l|}{ A. Kegiatan Pendahuluan } \\
\hline 1. Guru mengucapkan salam dan mengajak siswa untuk berdoa & 3 & 3.5 \\
\hline 2. Guru mengecek kehadiran siswa & 3 & 3.5 \\
\hline 3. Melakukan apersepsi & 2.5 & 3.5 \\
\hline 4. Guru menyampaikan tujuan pembelajaran & 3.5 & 3 \\
\hline \multicolumn{3}{|l|}{ B. Kegiatan inti } \\
\hline 5. Guru mengarahkan siwa membentuk kelompok awal & 2 & 3.5 \\
\hline 6. Membagikan LKS kepada siswa untuk didiskusikan & 3 & 4 \\
\hline 7. Siswa berdiskusi dikelompoknya masing-masing & 2.5 & 3 \\
\hline $\begin{array}{l}\text { 8. Guru mengarahkan siswa yang mengerjakan soal } \\
\text { membentuk kelompok ahli yang anggotanya membentuk } \\
\text { perwakilan dari kelompok asal }\end{array}$ & 3 & 4 \\
\hline $\begin{array}{l}\text { 9. Dikelompk ahli siswa berdiskusi dengan sesameaanggota } \\
\text { kelompok ahli untuk menjadi ahli tentang bidang yang } \\
\text { menjadi tugasnya }\end{array}$ & 2.5 & 3.5 \\
\hline $\begin{array}{l}\text { 10. Setelah selesai kelompok ahli berdiskusi anggota kelompok } \\
\text { asal untuk menjelaskan dan member pemahaman tentang } \\
\text { hasil diskusi dikelompok awal }\end{array}$ & 3 & 3 \\
\hline $\begin{array}{l}\text { 11. Menunjuk masing-masing kelompok untuk } \\
\text { mempresentasekan hasil diskusi dari kelompok ahli }\end{array}$ & 2.5 & 3.5 \\
\hline $\begin{array}{l}\text { 12. Setelah setiap kelompok mendapatkan kesempatan untuk } \\
\text { mempresentasekan hasil diskusinya guru menanggapi } \\
\text { tentang hasil siswa }\end{array}$ & 3 & 3.5 \\
\hline $\begin{array}{l}\text { 13. Memberikan penghargaan pada kelompok atas diskusi yang } \\
\text { telah dilakukan }\end{array}$ & 2.5 & 4 \\
\hline \multicolumn{3}{|l|}{ C. Penutup } \\
\hline 14. Guru bersama siswa Menyimpulkan hasil diskusi & 3 & 3 \\
\hline $\begin{array}{l}\text { 15. Guru melakukan refleksi atas pembelajaran yang telah } \\
\text { dilakukan }\end{array}$ & 3 & 3 \\
\hline 16. Guru memberikan soal latihan untuk dikerjakan dirumah & 3 & 3.5 \\
\hline 17. Guru menutup pembalajaran & 3 & 4 \\
\hline Rata-rata & 2.8 & 3.5 \\
\hline kategori & cukup & Baik \\
\hline
\end{tabular}




\section{Sumber: Data diolah (2017)}

Berdasarkan tabel 3.2 diatas menujukkan bahwa skor rata-rata aktivitas mengajar guru untuk setiap satuan aktivitasnya skor tertinggi berada pada angka nomor 14, 15, 16 dan 17 yaitu guru bersama siswa menyimpulkan hasil diskusi, guru melakukan refleksi atas pembelajaran yang telah dilakukan, guru memberikan soal latihan untuk dikerjakan dirumah, guru menutup pembalajaran untuk satuan

\section{Gambar 3.2. Skor rata-rata ktifitas mengajar guru Siklus I dan II}

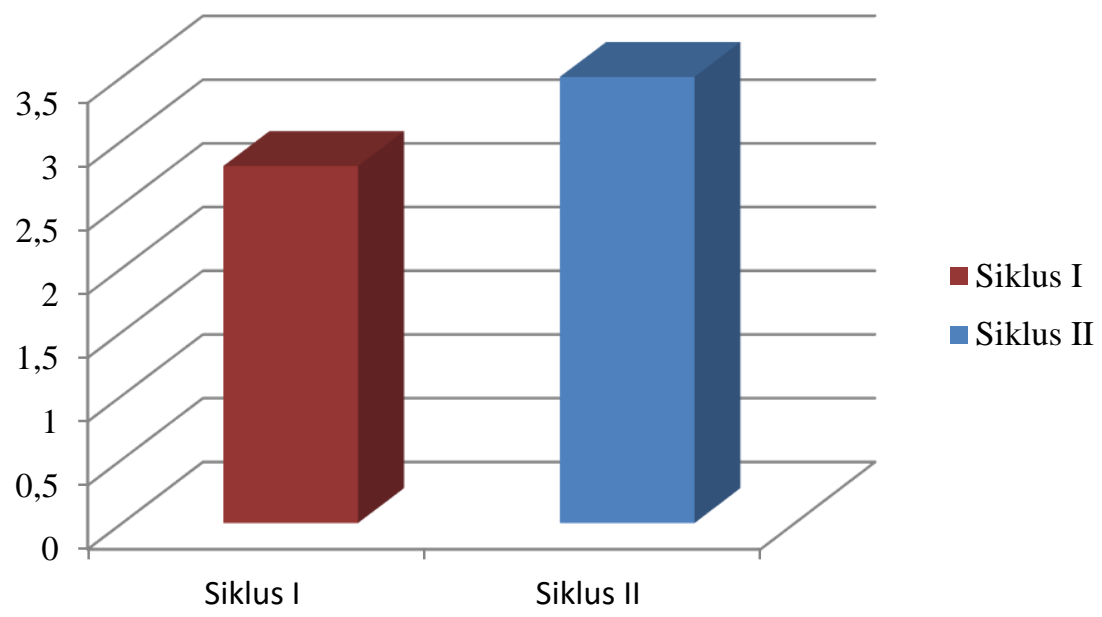

Berdasarkan Gambar 2 di atas, diperoleh gambaran bahwa aktivitas mengajar guru dalam kegiatan belajar mengajar dengan pendekatan pembelajaran Kooperatif tipe Jigsaw cenderung mengalami peningkatan. Hal ini ditunjukkan oleh skor rata-rata aktivitas mengajar guru pada siklus I sebesar 2,8 dan pada siklus II aktivitas mengalami peningkatan menjadi 3,5.

\section{Data Hasil Belajar Siswa}

Setelah diterapkan pendekatan pembelajaran Kooperatif tipe Jigsaw dalam aktivitasnya yaitu 2,5 dan pada siklus II meningkat menjadi 4 , selain itu skor ratarata aktivitas mengajar guru untuk setiap siklusnya juga mengalami peningkatan pada siklus I 2,8 dan pada siklus II menjadi 3,5 sehingga indikator keberhasilan dalam penelitian ini tercapai.

Tabel 3.3. Analisis Hasil Belajar Siswa

\begin{tabular}{ccc}
\hline Analisis Hasil Belajar Siswa & Siklus I & Siklus II \\
\hline Nilai Rata-rata & 72.4 & 76.4 \\
\hline Nilai Maksimum & 87.5 & 93.75 \\
\hline Nilai Minimum & 50 & 56.25 \\
\hline Jumlah Tuntas & 21 & 26 \\
\hline Jumlah TidakTuntas & 10 & 5 \\
\hline
\end{tabular}




\begin{tabular}{ccc}
\hline Persentase ST (\%) & 67.7 & 83.9 \\
\hline Persentase BT (\%) & 32.3 & 16.1 \\
\hline
\end{tabular}

Untuk lebih jelas, persentase ketuntasan hasil belajar siswa pada siklus I dan siklus II berdasarkan data hasil belajar yang telah dianalisis dapat dilihat pada gambar 3.3 dibawah ini :

\section{Diagram 3.3. Analisis Ketuntasan Belajar Siswa}

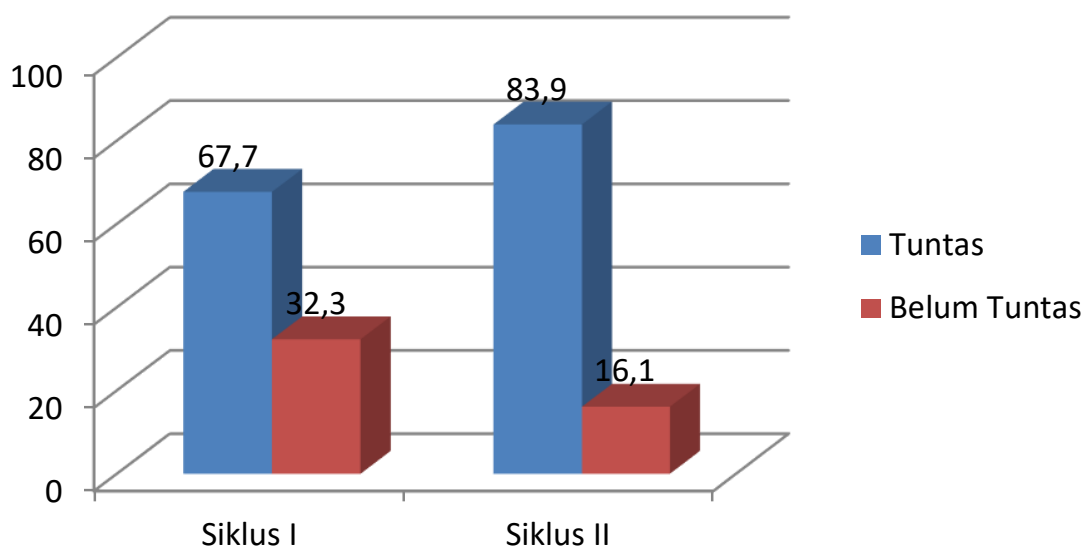

\section{PEMBAHASAN}

\section{Aktivitas Belajar Siswa dan Aktivitas Mengajar Guru}

Berdasarkan hasil pengamatan pada pelaksanaan tindakan siklus I dan II, baik persentase aktivitas guru maupun persentase aktivitas siswa menunjukkan peningkatan. Dalam hal ini pengamatan pada setiap siklus baik siklus I maupun siklus II menunjukkan peningkatan kearah yang lebih baik, dimana rata-rata aktivitas siswa dapat dilihat pada table 4.1 yaitu pada siklus I sebesar 2,6 dan pada siklus II sebesar 3,3. Pada siklus I ada beberapa aktivitas siswa yang tergolong kurang dimana siswa masih takut bertanya maupun mengungkapakan jawaban kepada guru dan masih sulit untuk bergabung dengan kelompok yang bukan teman dekatnya.
Sedangkan pada aktivitas mengajar guru, berdasarkan indicator permasalah yaitu bagaimana gambaran aktivitas mengajar guru dengan menerapkan pendekatan Kooperatif tipe Jigsaw, dapat dijelaskan bahwa aktivitas mengajar guru pada setiap siklus baik siklus I maupun siklus II yang menunjukkan peningkatan kearah yang lebih baik dimana rata-rata aktivitas mengajar guru dapat dilihat pada tabel 4.2 yaitu pada siklus I sebesar 2,8 dengan kategori cukup kemudian meningkat pada siklus II sebesar 3,5 dengan kategori baik. Pada siklus I ini, pengelolaan pembelajaran yang dilakukan oleh guru belum sesuai dengaan langkahlangkah pendekatan pembelajaran Kooperatif tipe Jigsaw, dimana pada aspek terendahnya terdapat pada indikator memotivasi siswa. Dan indicator lainnya yang perlu ditingkatkan yaitu pada indicator menyampaikan tujuan, menjelaskan perangkat yang dibutuhkan, membangkitkan 
pengetahuan awal siswa dan mengajukan pertanyaan. danpada siklus kedua guru pun melakukan refleksi dan beberapa perbaikan pada indicator yang dirasa kurang sehingga hasilnya sudah mengalami peningkatan pada setiap aspek indikatornya.

Dengan meningkatnya aktivitas belajar siswa dan aktivitas mengajar guru dalam pembelajaran setelah diterapkan pendekatan Kooperatif tipe Jigsawdan ratarata aktivitas mengajar guru pun meningkat maka penelitian ini dihentikan karena sudah mencapai indikator yang diharapkan.

\section{Hasil Belajar Siswa}

Ketuntasan suatu tindakan terhadap hasil belajar siswa dapat dilihat dari nilai rata-rata kelas, begitu juga halnya dengan ketuntasan siswa kelas $\mathrm{VII}_{\mathrm{B}} \mathrm{MTs}$ Negeri I Konawe Selatan dengan menerapkan pendekatan kooperatif tipe Jigsaw. Disamping itu, dalam menentukan siswa yang mengalami ketuntasan hasil belajar siswa dapat dilihat dari standar KKM yang telah ditetapkan. Sebagaimana telah dijelaskan pada Bab III siswa kelas VII $_{\mathrm{B}} \mathrm{MTs}$ Negeri I Konawe Selatan. ketuntasan belajar ketika memenuhhi KKM 70. Dengan demikian, bila siswa yang memperoleh nilai tes akhir di bawah 70 maka siswa dinyatakan belum tuntas.

Berdasarkan hasil analisis deskriptif terhadap hasil belajar siswa pada siklus I seperti pada table 4.3, diperoleh sebaran nilai yaitu nilai minimum sebesar 50 dan nilai maksimum sebesar 80 , rata-rata hasil belajar siswa yang diukur menggunakan tes hasil belajar siswa sebesar 72. Pada kondisi ini tenyata terdapat 10 orang siswa atau $32 \%$ siswa yang nilainya masih dibawah KKM (Kreiteria Ketuntasan Minimum) yang ditentukan oleh sekolah yaitu $\geq 70$ dan 21 orang siswa atau 68\% siswa yang telah tuntas.

Dari hasil evaluasi tindakan siklus II menujukkan bahwa ketuntasan belajar siswa secara klasikal mengalami peningkatan dari siklus I. Hasil yang diperoleh dari tes siklus II ini menujukkan ketuntasan belajar yang mencapai $84 \%$ atau sebanyak 26 dari 31 siswa memperoleh nilai $\geq 70$ sedangkan persentase siswa yang tidak tuntas berkurang menjadi $16 \%$ atau hanya 5 siswa yang belum tuntas. Berdasarkan hasil yang diperoleh pada siklus II, maka penelitian ini dihentikan karena indikator keberhasilan dalam penelitian ini sudah tercapai yaitu minimal $80 \%$ siswa memperoleh nilai $\geq 70$ sesuai dengan KKM yang ditentukan oleh sekolah yaitu 70 . Sedangkan untuk nilai maximum dan minimum untuk setiap siklusnya juga mengalami peningkatan pada siklus pertama nilai maximum yang diperoleh siswa 80 sedangkan pada siklus kedua meningkat menjadi 90 begitu pula dengan nilai minimum siswa, pada siklus pertama nilai minimum yang diperoleh siswa 50 kemudian pada siklus kedua meningkat menjadi 60 .

Peningkatan tersebut membuktikan bahwa pendekatan pembelajaran yang digunakan dalam proses pembelajaran dapat memberikan kontribusi pada hasil belajar siswa yang mempengaruhi hasil belajar, aktivitas siswa dalam proses pembelajaran. Adapun masih adanya beberapa siswa yang belum tuntas diduga karena kurangnya kehadiran siswa dan belum maksimalnya peneliti melaksanakan tahap-tahap pembelajaran sehingga mengakibatkan siswa tersebut tidak mengetahui penjelasan mengenai materi yang akan disampaikan peneliti. Untuk itu peneliti dituntut untuk lebih baik lagi mengelola kelas dalam proses pembelajaran dari pertemuan ke pertemuan berikutnya.

Berdasarkan data yang telah diuraikan di atas bahwa pendekatan Kooperatif tipe Jigsawdapat meningkatkan hasil belajar siswa. Hal tersebut sejalan dengan teori yang dikemukakan oleh Elaine B. Johnson $(2006 ; 215)$ bahwa model pembelajaran Kooperatif tipe Jigsaw) dapat mengembangkan dan meningkatkan pemahaman anak dalam memecahkan suatu masalah atau problem yang ada di lingkungannya, karena dengan berfikir kreatif melibatkan rasa ingin tahu bertanya siswa sehingga permasalahan itu terpecahkan dengan menghubungkan antara 
permasalahan dengan konteks kehidupan nyata mereka.

Oleh karenanya hipotesis yang diajukan yaitu penerapan pendekatan pembelajaran Kooperatif tipe Jigsawdapat meningkatkan hasil belajar siswa pada materi peta, atlas dan globe di kelas $\mathrm{VII}_{\mathrm{B}}$ MTs Negeri I Konsel dapat diterima.

\section{KESIMPULAN}

Berdasarkan hasil penelitian tindakan kelas yaitu dengan menggunakan pendekatan pembelajaran Kooperatif tipe Jigsaw) pada materi Interaksi Manusia dengan Lingkungan di kelas VII ${ }_{B} M T s$ Negeri I Konsel, dapat disimpulkan sebagai berikut:

1. Gambaran aktivitas belajar IPS siswa kelas VII $_{B}$ MTs Negeri I Kendari pada materi pokok Interaksi Manusia dengan Lingkunga melalui pendekatan Kooperatif tipe Jigsawpada setiap siklus cenderung meningkat. Hal ini diunjukkan dengan skor rata-rata pada setiap siklus, dimana pada siklus I skor rata- aktivitas belajar siswa adalah 2,6 yang termasuk kategori Cukup dan meningkat pada siklus II menjadi 3,3 yang termasuk pada kategori Baik.

2. Gambaran aktivitas mengajar guru kelas VII $_{\mathrm{B}} \mathrm{MTs}$ Negeri I Konsel pada materi pokok Interaksi Manusia dengan Lingkungan melalui pendekatan Kooperatif tipe Jigsawpada setiap siklus cenderung meningkatkan sebesar 0,7. Hal ini diunjukkan dengan skor rata-rata pada setiap siklus, dimana pada siklus I skor rata- aktivitas mengajar guru adalah 2,8 yang termasuk kategori Cukup dan meningkat pada siklus II menjadi 3,5 yang termasuk pada kategori Baik.

3. Hasil belajar IPS geografi siswa kelas VII ${ }_{B} M T s$ Negeri I Konsel dapat meningkat melalui pendekatan pembelajaran Kooperatif tipe Jigsaw. Hal ini dapat dilihat dari hasil tes tindakan siklus I yakni siswa yang mencapai nilai $\geq 70$ berjumlah 21 orang atau persentase siswa yang tuntas mencapai $68 \%$ dengan nilai rata-rata 54\% meningkat pada siklus II yakni ketuntasan belajar sebesar $81 \%$ atau siswa yang memperoleh nilai $\geq 70$ berjumlah 26 orang dengan nilai ratarata 77 dengan peningkatan hasil belajar siklus I dan II mencapai $27 \%$. Sehingga dapat disimpukan bahwa siswa didalam kelas sudah mencapai KKM sekolah yakni 70,00 dengan persentase ketuntasan klasikal mencapai $80 \%$ setelah diterapkannya pendekatan pembelajaran Kooperatif tipe Jigsaw.

\section{DAFTAR PUSTAKA}

Alma, Buchari.2009. Guru Profesional Menguasai Metode dan Tempat Mengajar. Bandung: Alfabeta.

Dahar, Ratna Wilis. 2011. Teori-teori Belajar \& Pembelajaran. Bandung: Erlangga.

Dimyati \& Mujiono.2009. Belajar dan pembelajaran. Jakarta: PT Rineka Cipta

Hudoyo, Herman. 1988. Strategi Belajar Pkn. Jakarat: Depdikbud.

Ibrahim, Muslimin. 2000. Pembelajaran kooperatif. Surabaya: UNESA University.

Lie, Anita. 2002. Cooperative Learning: Mempraktekan Cooperative Learning di Ruang-ruang Kelas. Jakarta: PT. Grasindo.

Listyarti, Retno. 2012. Pendidikan Karakter dalam Metode Aktif, Inovatif dan Kreatif. Jakarta: Erlangga. 
Purwanto, Ngalim. 1992. Psikologi Pendidikan. Bandung: PT Remaja Rosdakarya.

Sardiman. 2007. Interaksi dan Motivasi Belajar Mengajar. Jakarta: PT. Raja Grafindo Persada.

Slameto. 1995. Belajar dan Faktor-faktor yang Mempengaruhinya. Jakarta: Rineka Cipta.

Sudjana, Nana. 2007. Dasar-dasar Proses Belajar Mengajar. Bandung: Sinar Baru Algensindo.

Winkel, W.S. 2007. Psikologi Pengajaran. Yogyakarta: Media Abadi. 